\title{
Alteromonas hispanica sp. nov., a polyunsaturated- fatty-acid-producing, halophilic bacterium isolated from Fuente de Piedra, southern Spain
}

\author{
Correspondence \\ Emilia Quesada \\ equesada@ugr.es
}

\author{
Fernando Martínez-Checa, Victoria Béjar, Inmaculada Llamas, \\ Ana del Moral and Emilia Quesada \\ Microbial Exopolysaccharide Research Group, Department of Microbiology, Faculty of
Pharmacy, Cartuja Campus, University of Granada, 18071 Granada, Spain
}

Strain $\mathrm{F}-32^{\top}$, which produces exopolysaccharides and contains polyunsaturated fatty acids, was isolated from a hypersaline water sample collected from Fuente de Piedra (southern Spain). Phylogenetic analyses indicated conclusively that the strain in question belonged to the genus Alteromonas. Phenotypic tests showed that it could be assigned to the genus Alteromonas although it had a number of distinctive characteristics: it is moderately halophilic, growing best with 7.5-10\% w/v NaCl; it grows at $4{ }^{\circ} \mathrm{C}$ and produces $\mathrm{H}_{2} \mathrm{~S}$; it does not grow with D-cellobiose, $\mathrm{D}$-fructose, D-galactose, D-glucose or lactose as sole sources of carbon and energy; and its fatty-acid profile is typical of Alteromonas but it also contains a large amount of an unusual acid with three double bonds $[18: 3 \omega 6 c(6,9,12) ; 5 \cdot 01 \%, \mathrm{w} / \mathrm{v}]$. The major isoprenoid quinone is $Q_{8}$. The DNA G $+C$ content is $46.3 \mathrm{~mol} \%$. The phylogenetic, phenotypic and genetic properties of strain $\mathrm{F}-32^{\top}$ place it within a novel species, for which the name Alteromonas hispanica sp. nov. is proposed. The type strain is $\mathrm{F}-32^{\top}\left(=\right.$ CECT $7067^{\top}=$ LMG $\left.22958^{\top}\right)$.
The genus Alteromonas was isolated and named by Baumann et al. (1972) [description emended by Gauthier et al. (1995) and later by Van Trappen et al. (2004)] and originally contained a phylogenetically and phenotypically heterogeneous group of Gram-negative, heterotrophic, marine bacteria, motile by a single polar flagellum. Many of its species, however, have gradually been reclassified into other genera such as Marinomonas, Pseudoalteromonas and Shewanella (Van Landschoot \& de Ley, 1983; MacDonell \& Colwell, 1985; Coyne et al., 1989; Gauthier et al., 1995; Sawabe et al., 2000; Ivanova et al., 2000, 2001). Nowadays Alteromonas comprises only four recognized species: Alteromonas macleodii (Baumann et al., 1972, 1984; Gauthier et al., 1995; Yi et al., 2004), Alteromonas marina (Yoon et al., 2003), Alteromonas stellipolaris (Van Trappen et al., 2004) and Alteromonas litorea (Yoon et al., 2004). Together with the genera Glaciecola (Bowman et al., 1998) and Aestuariibacter (Yi et al., 2004), it is included within the family Alteromonadaceae (Ivanova et al., 2004).

Published online ahead of print on 15 July 2005 as DOI 10.1099/ ijs.0.63809-0.

Abbreviations: EPS, exopolysaccharide; PHB, poly- $\beta$-hydroxybutyrate; PUFA, polyunsaturated fatty acid.

The GenBank/EMBL/DDBJ accession number for the 16S rRNA gene sequence of Alteromonas hispanica $\mathrm{F}-32^{\top}$ is AY926460.
The members of the Alteromonadaceae are Gram-negative, rod-shaped, motile bacteria that do not form endospores or microcysts. They are chemo-organotrophs, have a respiratory metabolism and use oxygen as electron acceptor. They do not denitrify or have dihydrolase activity. All the species require $\mathrm{Na}^{+}$for growth and in most of them the major isoprenoid

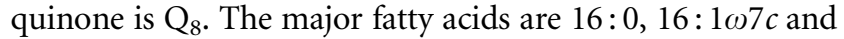
$18: 1 \omega 7 c$. All the species have been isolated from marine habitats (coastal sea waters and marine invertebrates). The family is a member of the Gammaproteobacteria with the following nucleotide sequence characteristics: 304 (A), 734 (A), $736(\mathrm{~T}), 770$ (T), 809 (A). The type genus is Alteromonas (Ivanova et al., 2004).

Van Trappen et al. (2004) made the last emended description of Alteromonas, which was based on Gauthier et al. (1995), when they discovered that members of the genus were prosthecate, budding bacteria. In addition to the traits reported for the family, the genus also includes bacteria which are catalase- and oxidase-positive, unpigmented and not luminescent. Species of the genus do not usually grow at $4{ }^{\circ} \mathrm{C}$, do not accumulate poly- $\beta$-hydroxybutyrate (PHB) and require a sea-water base for growth but not organic growth factors. A. macleodii, A. marina and A. stellipolaris produce buds and prostheca when they grow at low temperatures $\left(12-20{ }^{\circ} \mathrm{C}\right)$ for 3 or more days in complex media with added sea salts. The G+C content of the DNA is 44 to $47 \mathrm{~mol} \%$. The type species is A. macleodii. 
In this study we describe strain $\mathrm{F}-32^{\mathrm{T}}$ of Alteromonas, for which we propose the name Alteromonas hispanica. This strain is the only representative of the genus Alteromonas identified so far that has been isolated from an inland hypersaline habitat and produces polyunsaturated fatty acids (PUFAs) at a relatively high incubation temperature $\left(32^{\circ} \mathrm{C}\right)$, which contradicts the notion that only barophilic and psychrophilic marine species are able to produce significant levels of PUFAs (Nogi et al., 1998; Russell \& Nichols, 1999).

The strain studied here was isolated in 1998 from a hypersaline water sample taken from Fuente de Piedra (Málaga, southern Spain), an inland, hypersaline wetland, during a wide research programme aimed at discovering novel halophilic bacteria for biotechnological purposes (Martínez-Cánovas et al., 2004; Quesada et al., 2004). Strain F-32 ${ }^{\mathrm{T}}$ was isolated using MY medium (Moraine \& Rogovin, 1966), supplemented with $10 \% \mathrm{w} / \mathrm{v}$ marine salts (Rodríguez-Valera et al., 1981). The strain was kept and routinely grown in MY medium, with the addition of $7 \cdot 5 \% \mathrm{w} / \mathrm{v}$ marine salts for optimum growth. Strain F- $32^{\mathrm{T}}$ was originally characterized phenotypically by Martínez-Cánovas et al. (2004) by means of 135 tests. Its flagellation pattern was determined in this work by transmission electron microscopy of negatively stained cells. The phenotypic data are given in the species description. Table 1 shows the main phenotypic differences between strain $\mathrm{F}-32^{\mathrm{T}}$ and the other four species of the genus Alteromonas. The same table contains the $\mathrm{G}+\mathrm{C}$ content of strain $\mathrm{F}-32^{\mathrm{T}}$ estimated from the midpoint value $\left(T_{\mathrm{m}}\right)$ of the DNA thermal denaturation profile, as described in Martínez-Cánovas et al. (2004).

Table 1. Phenotypic characteristics and DNA G+C content distinguishing Alteromonas hispanica from the other species of Alteromonas

Data from Baumann et al. (1972, 1984), Gauthier et al. (1995), Ivanova et al. (2004), Van Trappen et al. (2004), Yi et al. (2004), Yoon et al. $(2003,2004)$ and from this study. ND, Not determined; $(+)$ the majority of the strains are positive; w, weakly positive reaction.

\begin{tabular}{|c|c|c|c|c|c|}
\hline Characteristic & $\mathrm{F}-32^{\mathrm{T}}$ & A. macleodii & A. marina & A. stellipolaris & A. litorea \\
\hline Origin of the type strain & $\begin{array}{c}\text { Hypersaline water, } \\
\text { Fuente de Piedra } \\
\text { (Málaga, southern Spain) }\end{array}$ & Sea water & $\begin{array}{c}\text { Sea water, East Sea } \\
\text { in Korea }\end{array}$ & Antarctic sea water & $\begin{array}{l}\text { Intertidal sediment, } \\
\text { Yellow Sea of Korea }\end{array}$ \\
\hline Cell size $(\mu \mathrm{m})$ & $1-2 \times 0.75$ & $1 \cdot 8-2 \cdot 5 \times 0 \cdot 9-1 \cdot 3$ & $2 \cdot 5-4 \times 1-1 \cdot 2$ & $2-7 \times 0 \cdot 4$ & $2-4 \times 0 \cdot 9-1 \cdot 2$ \\
\hline Bud/prosthecum & + & + & + & + & $\mathrm{ND}$ \\
\hline Pigmentation & Cream & Cream & Cream & Brown diffuse & Cream \\
\hline PHB & + & - & $\mathrm{ND}$ & - & $\mathrm{ND}$ \\
\hline EPS & + & ND & - & ND & ND \\
\hline \multicolumn{6}{|l|}{$\begin{array}{l}\mathrm{NaCl} \text { concentration for } \\
\text { growth }(\% \mathrm{w} / \mathrm{v})\end{array}$} \\
\hline Range & $7 \cdot 5-15$ & ND & $2-15$ & $1-10$ & $2-14$ \\
\hline Optimum & $7 \cdot 5-10$ & ND & $2-5$ & $\mathrm{ND}$ & $2-5$ \\
\hline \multicolumn{6}{|l|}{$\begin{array}{l}\text { Sea-salt concentration for } \\
\text { growth }(\% \mathrm{w} / \mathrm{v})\end{array}$} \\
\hline Range & $3-20$ & ND & ND & ND & ND \\
\hline Optimum & $5-15$ & ND & ND & ND & ND \\
\hline Growth at $4{ }^{\circ} \mathrm{C}$ & + & - & + & + & - \\
\hline \multicolumn{6}{|l|}{ Acid from: } \\
\hline Glucose & - & + & - & - & - \\
\hline Maltose & + & + & - & $\mathrm{ND}$ & + \\
\hline Sucrose & - & + & + & $\mathrm{W}$ & - \\
\hline D-Trehalose & - & + & + & + & + \\
\hline $\mathrm{H}_{2} \mathrm{~S}$ from cysteine & + & ND & - & - & - \\
\hline \multicolumn{6}{|l|}{ Growth on: } \\
\hline D-Cellobiose & - & + & ND & $(+)$ & ND \\
\hline D-Fructose & - & + & + & + & + \\
\hline D-Galactose & - & + & + & + & + \\
\hline D-Glucose & - & + & + & + & + \\
\hline Lactose & - & + & + & $(+)$ & + \\
\hline D-Mannitol & + & + & - & + & - \\
\hline L-Serine & - & - & ND & $\mathrm{w}$ & ND \\
\hline $\mathrm{G}+\mathrm{C}$ content $(\mathrm{mol} \%)$ & $46 \cdot 3$ & $44 \cdot 9-46 \cdot 4$ & $44-45$ & $43-45$ & 46 \\
\hline
\end{tabular}



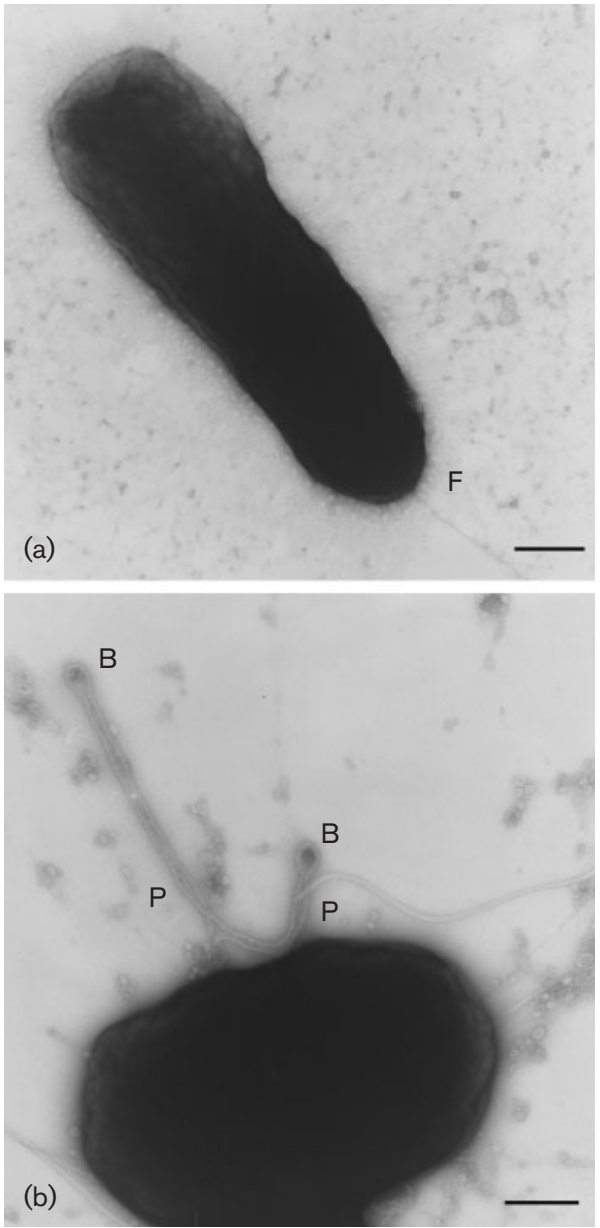

Fig. 1. Electron micrographs of negatively stained preparations of cells of strain $\mathrm{F}-32^{T}$ showing (a) a polar flagellum $(\mathrm{F})$ and (b) prostheca $(P)$ and buds $(B)$. Cells were stained with $1 \%$ $\mathrm{w} / \mathrm{v}$ uranyl acetate in $0.4 \% \mathrm{w} / \mathrm{v}$ sucrose. Bars, $0.3 \mu \mathrm{m}$.
Colonies used for the analysis of prostheca and buds were grown on MY $(7 \cdot 5 \% \mathrm{w} / \mathrm{v})$ for 7 days at $12{ }^{\circ} \mathrm{C}$, as recommended by Van Trappen et al. (2004) (Fig. 1). Exopolysaccharide (EPS) and PHB granules were observed in cells grown on the same medium after 1 day's incubation at $32{ }^{\circ} \mathrm{C}$ (Fig. 2). Transmission electron micrographs were taken using the methods described by Bouchotroch et al. (2001).

Phylogenetic analyses were made according to Bouchotroch et al. (2001). We determined the near-complete 16S rRNA gene sequence of strain $\mathrm{F}-32^{\mathrm{T}}(1479 \mathrm{bp})$. The sequence obtained was compared to reference 16S rRNA gene sequences available in the GenBank, EMBL and DDBJ databases obtained from the National Centre of Biotechnology Information database using the BLAST search. Phylogenetic analysis was made using the software MEGA version 3.0 (Kumar et al., 2004) after multiple data alignments by CLUSTAL_X (Thompson et al., 1997). Distances and clustering were determined using the neighbour-joining and maximumparsimony methods. The stability of clusters was ascertained by performing a bootstrap analysis (1000 replications). The phylogenetic tree obtained by neighbour-joining is shown in Fig. 3. The maximum-parsimony algorithm gave a similar result (data not shown). Our results indicate conclusively that strain $\mathrm{F}-32^{\mathrm{T}}$ belongs to the genus Alteromonas, showing 95.3-97.4\% similarity to the other four species within the genus. As expected, the next closest neighbours were the other members of the family Alteromonadaceae, Glaciecola (Ivanova et al., 2004) and Aestuariibacter (Yi et al., 2004). The nucleotide-sequence characteristics of the family Alteromonadaceae, 304 (A), 734 (A), 736 (T), 770 (T), 809 (A) (Ivanova et al., 2004), were present in strain F-32 ${ }^{\mathrm{T}}$.

The fatty acids and quinones were analysed at the DSMZ (Deutsche Sammlung von Mikroorganismen und Zellkulturen $\mathrm{GmbH}$ ) in a culture of strain $\mathrm{F}-32^{\mathrm{T}}$ made at $32^{\circ} \mathrm{C}$ in
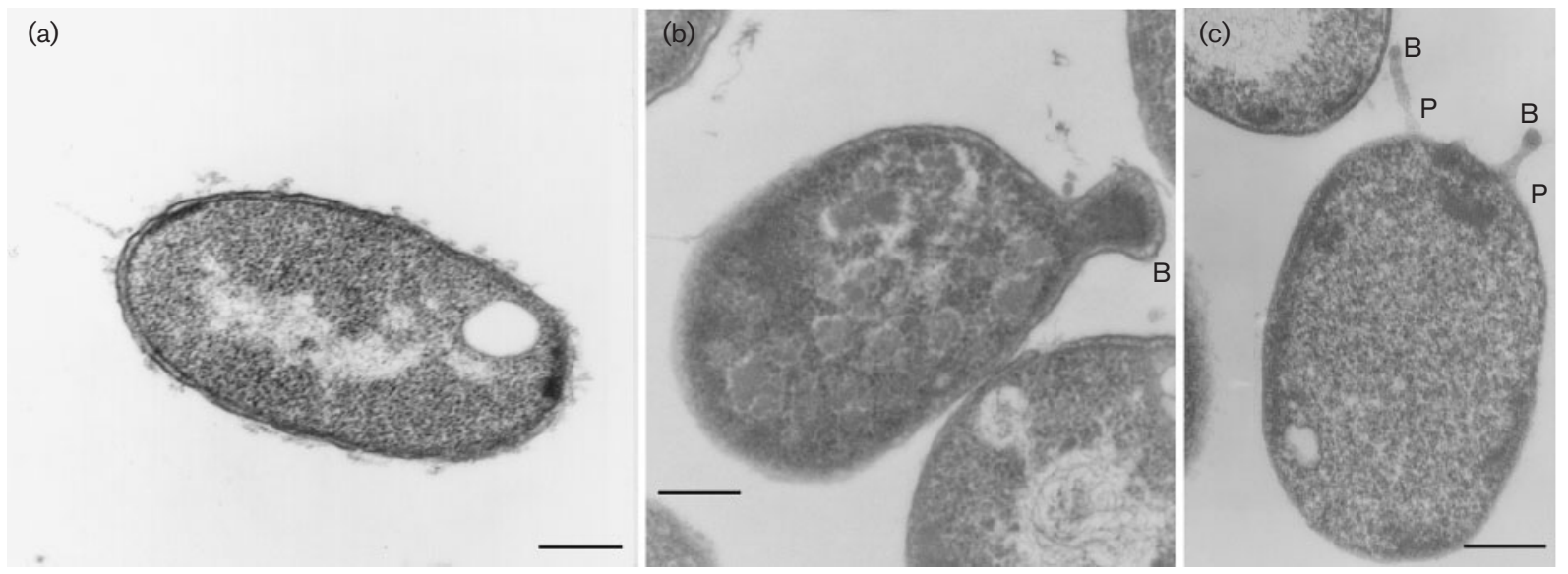

Fig. 2. Electron micrographs of thin-section preparations of cells of strain $F-32^{\top}$ showing (a) EPS and PHB granule, (b) bud formations $(B)$ and $(c)$ prostheca $(P)$. Thin-section preparations were stained with lead citrate and $1 \% \mathrm{w} / \mathrm{v}$ uranyl acetate. Bars, $0.3 \mu \mathrm{m}$. 


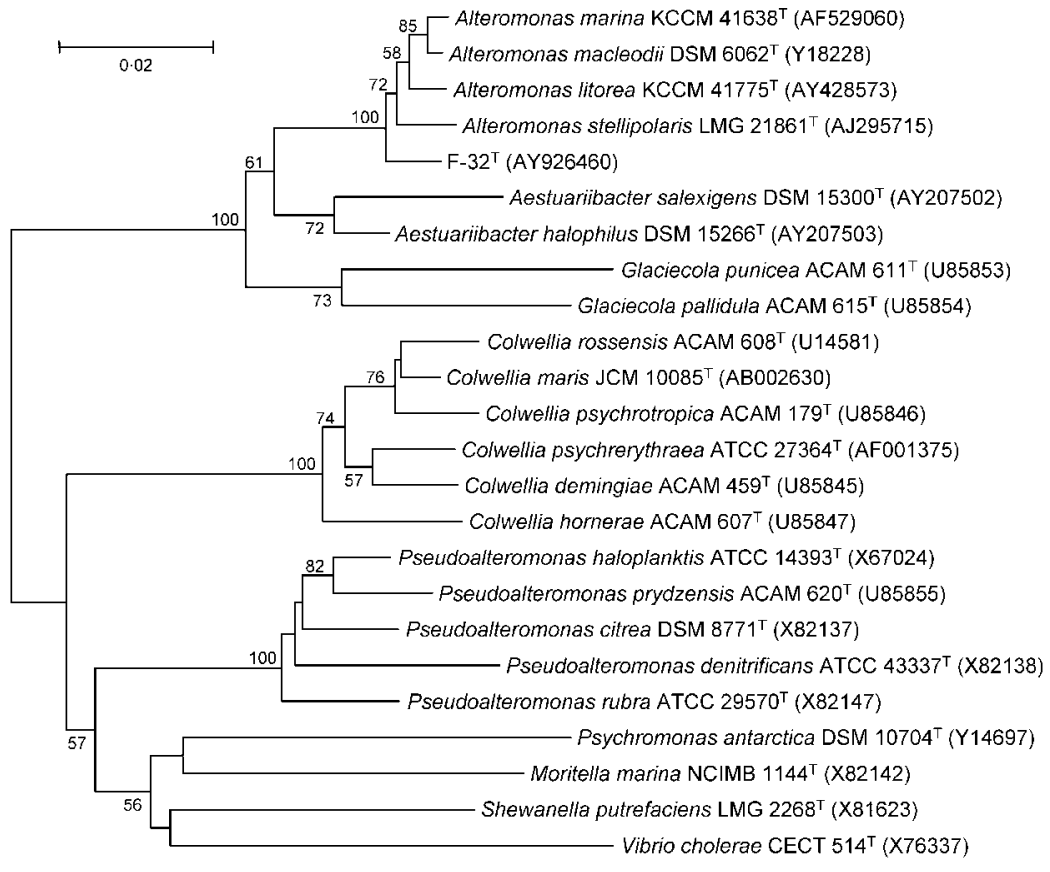

Fig. 3. Phylogenetic relationship between Alteromonas hispanica $\mathrm{F}-32^{\top}$ and the other species of the genus Alteromonas, together with members of the family Alteromonadaceae and other related gammaproteobacteria. The tree was constructed using the neighbourjoining algorithm. Only bootstrap values above $50 \%$ are shown (1000 replications). Bar, $2 \%$ estimated sequence divergence.
MY $7 \cdot 5 \% \mathrm{w} / \mathrm{v}$ (see Table 2). The fatty-acid profile of strain $\mathrm{F}-32^{\mathrm{T}}$ was typical of Alteromonas species, with a predominance of $16: 0,16: 1 \omega 7 c$ and $18: 1 \omega 7 c$, but it also contains large amounts of $16: 0 \mathrm{~N}$ alcohol, 17:0 10-methyl, 18:0 and an unusual unsaturated fatty acid $[18: 3 \omega 6 c(6,9,12)]$. PUFAs are rare in mesophilic bacteria and have not been found so far in any Alteromonas species. The predominant respiratory quinone was $\mathrm{Q}_{8}$ (ubiquinone $8,96.5 \%$; ubiquinone $7,3 \cdot 5 \%)$.

In conclusion, polyphasic analyses demonstrate that the new isolate belongs to a consistent taxon and represents a novel

Table 2. Major fatty acids in the Alteromonas species

Data from this work and from Van Trappen et al. (2004) and Yoon et al. (2004). -, Not detected or less than $1 \%$.

\begin{tabular}{|lccccc|}
\hline Fatty acid & F-32 & A. macleodii & A. marina & A. stellipolaris & A. litorea \\
\hline $10: 0$ 3-OH & $1 \cdot 20$ & $1 \cdot 5$ & $1 \cdot 3$ & - & $1 \cdot 4$ \\
$11: 0$ 3-OH & - & - & $1 \cdot 0$ & - & $1 \cdot 2$ \\
$12: 0$ & $1 \cdot 77$ & $2 \cdot 5$ & $2 \cdot 9$ & - & $2 \cdot 7$ \\
$12: 03-\mathrm{OH}$ & $1 \cdot 06$ & $1 \cdot 2$ & $1 \cdot 1$ & - & $1 \cdot 1$ \\
$14: 0$ & $2 \cdot 07$ & $2 \cdot 5$ & $2 \cdot 6$ & - & $3 \cdot 6$ \\
$15: 0$ & - & $2 \cdot 5$ & $2 \cdot 8$ & - & $2 \cdot 1$ \\
$15: 1 \omega 8 c$ & - & $1 \cdot 7$ & $1 \cdot 1$ & - & $1 \cdot 0$ \\
$16: 0$ & $13 \cdot 77$ & $23 \cdot 8$ & $21 \cdot 2$ & $12 \cdot 6$ & $20 \cdot 0$ \\
$16: 0$ iso & - & $1 \cdot 1$ & - & - & - \\
$16: 0 \mathrm{~N}$ alcohol & $7 \cdot 35$ & $6 \cdot 6$ & $3 \cdot 2$ & - & $5 \cdot 6$ \\
$16: 1 \omega 7 c$ alcohol & $1 \cdot 167$ & $4 \cdot 3$ & $1 \cdot 9$ & - & $5 \cdot 8$ \\
$17: 0$ & - & $2 \cdot 6$ & $3 \cdot 2$ & - & $2 \cdot 9$ \\
$17: 0$ 10-methyl & $15 \cdot 63$ & $2 \cdot 9$ & $1 \cdot 5$ & - & $4 \cdot 5$ \\
$17: 1 \omega 8 c$ & - & $4 \cdot 3$ & $5 \cdot 6$ & $9 \cdot 4$ & $3 \cdot 6$ \\
$18: 1 \omega 7 c$ & $14 \cdot 30$ & $9 \cdot 9$ & $11 \cdot 8$ & $18 \cdot 0$ & $12 \cdot 5$ \\
$18: 0$ & $5 \cdot 89$ & - & - & - & - \\
$18: 3 \omega 6 c(6,9,12)$ & $5 \cdot 01$ & - & - & - & - \\
$15: 0$ iso 2-OH/16: $1 \omega 7 c$ & $22 \cdot 10$ & $24 \cdot 6$ & $28 \cdot 5$ & $27 \cdot 3$ & $20 \cdot 0$ \\
$16: 1$ iso I/14:0 3-OH & $2 \cdot 57$ & $3 \cdot 3$ & $3 \cdot 6$ & - & $3 \cdot 0$ \\
& & & & & \\
\hline
\end{tabular}


species within the genus Alteromonas, for which we propose the name Alteromonas hispanica.

\section{Description of Alteromonas hispanica sp. nov.}

Alteromonas hispanica (his.pa'ni.ca. L. fem. adj. hispanica Spanish).

The cells are straight rods, $1-2 \mu \mathrm{m}$ long and $0.75 \mu \mathrm{m}$ wide, appearing either singly or in pairs. They stain Gram-negative and are motile by one polar flagellum. They produce buds, prostheca and PHB. No spores are observed under any conditions. Colonies are cream coloured, round, convex and mucoid. EPS is produced. Growth pattern is uniform in a liquid medium. The bacterium is chemo-organotrophic and strictly aerobic, i.e. anaerobic respiration with nitrate, nitrite or fumarate is negative. Catalase and oxidase are positive. It produces acids from maltose but not from any of the following carbohydrates: adonitol, L-arabinose, Dcellobiose, D-fructose, D-galactose, D-glucose, myo-inositol, lactose, D-mannitol, mannose, D-melezitose, L-rhamnose, D-salicin, D-sorbitol, sorbose, sucrose and trehalose. It is moderately halophilic, capable of growing in $\mathrm{NaCl}$ concentrations of $7 \cdot 5$ to $15 \% \mathrm{w} / \mathrm{v}$ (optimum $7 \cdot 5-10 \%$ ). It does not require additional magnesium or potassium salts. It grows within the temperature range of 4 to $40^{\circ} \mathrm{C}$ (optimum $32^{\circ} \mathrm{C}$ ) and at $\mathrm{pH}$ values between 5 and 10 (optimum 7-8). It shows positive activity for ONPG, phosphatase, selenite reduction, $\mathrm{H}_{2} \mathrm{~S}$ production from cysteine and hydrolysis of aesculin, casein, gelatin, Tween 20 , Tween 80 , starch and DNA. It is negative for nitrate and nitrite reduction, urease, lecithinase phenylalanine deaminase, gluconate oxidation, growth on cetrimide agar, growth on MacConkey agar, indole, methyl red, Voges-Proskauer and haemolysis. It grows in synthetic media supplemented with maltose and mannitol as sole sources of carbon and energy. It does not grow in synthetic media supplemented with the following sole sources of carbon and energy, or carbon, nitrogen and energy: aesculin, L-arabinose, D-cellobiose, D-fructose, Dgalactose, D-glucose, lactose, D-mannose, D-melezitose, Lrhamnose, D-salicin, starch, D-trehalose, citrate, formate, fumarate, gluconate, lactate, malonate, propionate, succinate, adonitol, ethanol, myo-inositol, sorbitol, L-alanine, Lcysteine, L-histidine, DL-isoleucine, L-lysine, L-methionine, $\mathrm{L}$-serine and L-valine. It is susceptible to amoxicillin $(25 \mu \mathrm{g})$, ampicillin $(10 \mu \mathrm{g})$, carbenicillin $(100 \mu \mathrm{g})$, cefotaxime $(30 \mu \mathrm{g})$, chloramphenicol $(30 \mu \mathrm{g})$, erythromycin $(15 \mu \mathrm{g})$, kanamycin $(30 \mu \mathrm{g})$, nalidixic acid $(30 \mu \mathrm{g})$, nitrofurantoin $(300 \mu \mathrm{g})$, polymyxin B (300 UI), rifampicin $(30 \mu \mathrm{g})$, streptomycin $(10 \mu \mathrm{g})$, sulphamide $(250 \mu \mathrm{g})$, tobramycin $(10 \mu \mathrm{g})$ and trimetroprim/sulphametoxazol $(1 \cdot 25 / 23 \cdot 75 \mu \mathrm{g})$. It is resistant to cefoxitin $(30 \mu \mathrm{g})$. The principal fatty acids are (\%): $16: 0 \mathrm{~N}$ alcohol $(7 \cdot 35), 15: 0$ iso $2-\mathrm{OH} / 16: 1 \omega 7 c(22 \cdot 10)$, $16: 0 \quad(13 \cdot 77), \quad 17: 0 \quad 10$-methyl $(15 \cdot 63), \quad 18: 0 \quad(5 \cdot 89)$, $18: 3 \omega 6 c(6,9,12)(5 \cdot 01)$ and $18: 1 \omega 7 c(14 \cdot 30)$. DNA $\mathrm{G}+\mathrm{C}$ content is $46 \cdot 3 \mathrm{~mol} \%$ ( $T_{\mathrm{m}}$ method).
The type strain, F-32 ${ }^{\mathrm{T}}\left(=\right.$ CECT $7067^{\mathrm{T}}=$ LMG $\left.22958^{\mathrm{T}}\right)$, was isolated from a hypersaline water sample taken at Fuente de Piedra (Málaga, southern Spain).

\section{Acknowledgements}

This research was supported by grants from the Dirección General de Investigación Científica y Técnica (BOS2003-00498) and from the Consejería de Innovación, Ciencia y Empresa de la Junta de Andalucía, Spain. The authors are very grateful to Concepción Fernández and David Porcel for their expertise in the electron-microscope studies and to their colleague Dr J. Trout for revising the English text.

\section{References}

Baumann, L., Baumann, P., Mandel, M. \& Allen, R. D. (1972). Taxonomy of aerobic marine eubacteria. J Bacteriol 110, 402-429.

Baumann, P., Baumann, L., Bowditch, R. D. \& Beaman, B. (1984). Taxonomy of Alteromonas: A. nigrifaciens sp. nov., nom. rev.; A. macleodii; and A. haloplanktis. Int J Syst Bacteriol 34, 145-149.

Bouchotroch, S., Quesada, E., del Moral, A., Llamas, I. \& Béjar, V. (2001). Halomonas maura sp. nov., a novel moderately halophilic, exopolysaccharide-producing bacterium. Int J Syst Evol Microbiol 51, 1625-1632.

Bowman, J. P., McCammon, S. A., Brown, J. L. \& McMeekin, T. A. (1998). Glaciecola punicea gen. nov., sp. nov. and Glaciecola pallidula gen. nov., sp. nov.: psychrophilic bacteria from Antarctic sea-ice habitats. Int J Syst Bacteriol 48, 1213-1222.

Coyne, V. E., Pillidge, C. J., Sledjeski, D. D., Hori, H., Ortiz-Conde, B. A., Muir, D. G., Weiner, R. M. \& Colwell, R. R. (1989). Reclassification of Alteromonas colwelliana to the genus Shewanella by DNA-DNA hybridization, serology and $5 \mathrm{~S}$ ribosomal RNA sequence data. Syst Appl Microbiol 12, 275-279.

Gauthier, G., Gauthier, M. \& Christen, R. (1995). Phylogenetic analysis of the genera Alteromonas, Shewanella, and Moritella using genes coding for small-subunit rRNA sequences and division of the genus Alteromonas into two genera, Alteromonas (emended) and Pseudoalteromonas gen. nov., and proposal of twelve new species combinations. Int J Syst Bacteriol 45, 755-761.

Ivanova, E. P., Chun, J., Romanenko, L. A., Matte, M. E., Mikhailov, V. V., Frolova, G. M., Huq, A. \& Colwell, R. R. (2000). Reclassification of Alteromonas distincta Romanenko et al. 1995 as Pseudoalteromonas distincta comb. nov. Int J Syst Evol Microbiol 50, 141-144.

Ivanova, E. P., Romanenko, L. A., Matté, M. H. \& 10 other authors (2001). Retrieval of the species Alteromonas tetraodonis Simidu et al. 1990 as Pseudoalteromonas tetraodonis comb. nov. and emendation of description. Int J Syst Evol Microbiol 51, 1071-1078.

Ivanova, E. P., Flavier, S. \& Christen, R. (2004). Phylogenetic relationships among marine Alteromonas-like proteobacteria: emended description of the family Alteromonadaceae and proposal of Pseudoalteromonadaceae fam. nov., Colwelliaceae fam. nov., Shewanellaceae fam. nov., Moritellaceae fam. nov., Ferrimonadaceae fam. nov., Idiomarinaceae fam. nov. and Psychromonadaceae fam. nov. Int J Syst Evol Microbiol 54, 1773-1788.

Kumar, S., Tamura, K. \& Nei, M. (2004). MEGA3: integrated software for molecular evolutionary genetics analysis and sequence alignment. Brief Bioinform 5, 150-163.

MacDonell, M. T. \& Colwell, R. R. (1985). Phylogeny of the Vibrionaceae, and recommendation for two new genera, Listonella and Shewanella. Syst Appl Microbiol 6, 171-182.

Martínez-Cánovas, M. J., Quesada, E., Martínez-Checa, F. \& Béjar, V. (2004). A taxonomic study to establish the relationship between 
exopolysaccharide-producing bacterial strains living in diverse hypersaline habitats. Curr Microbiol 48, 348-353.

Moraine, R. A. \& Rogovin, P. (1966). Kinetics of polysaccharide B1459 fermentation. Biotechnol Bioeng 8, 511-524.

Nogi, Y., Kato, C. \& Horikoshi, K. (1998). Taxonomic studies of deep-sea barophilic Shewanella strains and description of Shewanella violacea sp. nov. Arch Microbiol 170, 331-338.

Quesada, E., Béjar, V., Ferrer, M. R. \& 8 other authors (2004). Moderately halophilic, exopolysaccharide-producing bacteria. In Halophilic Microorganisms, pp. 297-314. Edited by A. Ventosa. Heidelberg: Springer.

Rodríguez-Valera, F., Rúiz-Berraquero, F. \& Ramos-Cormenzana, A. (1981). Characteristics of the heterotrophic bacterial populations in hypersaline environments of different salt concentrations. Microb Ecol 7, 235-243.

Russell, N. J. \& Nichols, D. S. (1999). Polyunsaturated fatty acids in marine bacteria - a dogma rewritten. Microbiology 145, 767-779.

Sawabe, T., Tanaka, R., Iqbal, M. M., Tajima, K., Ezura, Y., Ivanova, E. P. \& Christen, R. (2000). Assignment of Alteromonas elyakovii KMM $162^{\mathrm{T}}$ and five strains isolated from spot-wounded fronds of Laminaria japonica to Pseudoalteromonas elyakovii comb. nov. and the extended description of the species. Int J Syst Evol Microbiol 50, 265-271.
Thompson, J. D., Gibson, T. J., Plewniak, K., Jeanmougin, F. \& Higgins, D. G. (1997). The CLUSTAL_X Windows interface: flexible strategies for multiple sequence alignment aided by quality analysis tools. Nucleic Acids Res 25, 4876-4882.

Van Landschoot, A. \& de Ley, J. (1983). Intra- and intergeneric similarities of the rRNA cistrons of Alteromonas, Marinomonas (gen. nov.) and some other Gram-negative bacteria. J Gen Microbiol 129, 3057-3074.

Van Trappen, S., Tan, T.-L., Yang, J., Mergaert, J. \& Swings, J. (2004). Alteromonas stellipolaris sp. nov., a novel, budding, prosthecate bacterium from Antarctic seas, and emended description of the genus Alteromonas. Int J Syst Evol Microbiol 54, 1157-1163.

Yi, H., Bae, K. S. \& Chun, J. (2004). Aestuariibacter salexigens gen. nov., sp. nov. and Aestuariibacter halophilus sp. nov., isolated from tidal flat sediment, and amended description of Alteromonas macleodii. Int J Syst Evol Microbiol 54, 571-576.

Yoon, J.-H., Kim, I. G., Kang, K. H., Oh, T.-K. \& Park, Y.-H. (2003). Alteromonas marina sp. nov., isolated from sea water of the East Sea in Korea. Int J Syst Evol Microbiol 53, 1625-1630.

Yoon, J.-H., Yeo, S.-H., Oh, T.-K. \& Park, Y.-H. (2004). Alteromonas litorea sp. nov., a slightly halophilic bacterium isolated from an intertidal sediment of the Yellow Sea in Korea. Int J Syst Evol Microbiol 54, 1197-1201. 